\title{
Public Participation and Political Culture: A Case Study of Voting Behavior in Jombang Regency
}

\author{
Hilmy Mochtar \\ Department of Political Science, Faculty of Social and Politics, Brawijaya University, Malang, Indonesia \\ Email: mirojulhuda@gmail.com
}

Received 11 August 2014; revised 20 September 2014; accepted 3 October 2014

Copyright (C) 2014 by author and Scientific Research Publishing Inc. This work is licensed under the Creative Commons Attribution International License (CC BY). http://creativecommons.org/licenses/by/4.0/

\section{c) (i) Open Access}

\begin{abstract}
This paper tries to describe a piece of the phenomena of shifting behavior of voters in Indonesia's democratic transition era. It focused on Jombang district of East Java's grassroots level. This study adopted an institutional approach to understanding local context of political and social institution as actors that have important roles in shifting behavior. The changing pattern of public participation not absolutely dependent on regulations had been made by the people, representative body or regional political leaders; but based on specific issues rooted from the geographical-economical and socio-religious conditions.
\end{abstract}

\section{Keywords}

Political Culture, Public Participation, Shifting Behavior

\section{Introduction}

National election and regional election are important parts of political process in the country during the reformation era. The election which is done in democratic and participative way won't result in political crisis. On the other hand, election which is done in undemocratic and non-participative way will make it possible for political crisis to arise. Public participation is being a must on a democratic election, even though public participation will be much affected by the political culture in the community, especially in the grassroots level (Mochtar, 2008). The emerging of public participation is pushed by the euphoria of successful reformation which reflects the strengthening of people demands to accelerate the democratization process (Mochtar, 2012). This also shows that public participation becomes non-separable part from political process in the grassroots level.

In every election there are at least three things that should be noticed. First, normatively there should be a 
guarantee for people to choose. Second, people should be given space so that participation could be grown. Third, public participation is not limited only to things related with power (like people legislative or public officer election), but also to things related with people's necessity in the grassroots level (such as people involvement in opposition movement to against policy which harm poor people).

In the reality of local politics, political party is responsible for the strengthening or weakening public participation especially in the large scale political parties such as Partai Demokrasi Indonesia Perjuangan (PDI P), Partai Kebangkitan Bangsa (PKB) and Partai Golongan Karya (Partai Golkar) ${ }^{1}$.

In this moment, the political leaders have become "new kings" in their party area. The main characteristic from this condition is centralistic character which sticks to the party institution at central level, whereas in regional level the party institution is merely the follower of the policies made by the central. For example, in the nomination of legislative members or regional public officers, there is a general assumption that if the party leaders on the central level consider a person as incapable to "buy people supports" (even though he/she is a very well-capable cadre in their region), he/she will never be able to be legislative or regional legislative candidates in their region. On the contrary, if the party leaders on the central level consider a person as capable to buy people supports, they will be approved to be legislative candidates (even though they are not cadre from that region).

Political life at the local level as above condition will cause a contradiction. On one side, it will make the regional party leaders will always be under pressure from the central leaders and vulnerable towards friction, while public participation which derive from grassroots will be diffused and tends to be pragmatic voters (for example, because of money politics). On the other side, the regional party leaders have more options and new political chance, whereas public participation in the grassroots level will be fused into new smaller groups and the voters will tend to be more rational.

Public participation on the national/regional election is democracy operationalization according to context and emerging political agenda, at least, it can be seen from two indications.

First, on the normative level, the embodiment of democracy as in the Acts No. 31/2002 about political party which is the revision of previously Acts (Acts No. 22/1999) and Acts No. 2/2008 which is the revision from the previous Acts. In Acts No. 31/2002 and also Acts No. 2/2008 there are democratic principles which stated in the sentences: ... freedom to unite, gather and give opinion is the part of human rights, freedom, equality, togetherness and honesty. Besides that, the democratic principles also stated in Acts No. 12/2003 about the election of Legislative Assembly, Regional Assembly and Regional Legislative Assembly. In Acts No. 12/2003, those things stated in consideration which relate with people sovereignty, people participation which is done according to principles of general, free, classified and honesty, to choose the assembly members who assure principle of representation, accountability and legitimation. Those basic principles of democracy also becoming consideration part of Acts No. 23/2003 about Presidential Election. Whereas Acts No. 22/2007 about National Election Organizer (Chapter 1 Article 1) state that coverage of national election has been widened that is not only vote for legislative members but also regional head leader directly².

Second, on the practical and empirical level, there are community groups with variant of background, ideological orientation, direction and purposes. Generally these groups normally called as civil society movement. This movement has given enough contribution for the acceleration of democratization process, as independent movement which has cross-religion supports as the basis. Normally big themes which become reference of this social movement are global issues which relate with human rights, empowerment, anti-discrimination, gender equality and et cetera. The rising of these groups is triggered by excessive state role in intervening non-governmental matters or because of state policies which give negative impacts to its people, so that the performance of these groups also depended on the completion of the related issues.

The political parties which are oriented of powers through the national election and also regional election, and also civil society movements which are oriented of the strengthening of the community through empowerment. Two types of social power and politics normatively have given space by Acts No. 31/2002, Acts No. 12/2003 and also Acts No. 2/2008. The political parties use it as an arena to compete for state power through legislative and executive, whereas civil society use it as accommodation as described in the institution of National Election Commission and Regional Election Commission as the organizers of the event.

${ }^{1}$ PDI P, PKB and Partai Golkar are the political parties on the local context in East Java province especially at Jombang district have dominant role in local legislative body or in every political events as such as direct election for the head of a district or governor.

${ }^{2}$ A Presdential direct election which has been done since June 2005, 2009, and 2014. 
Short exposure as above is only the small part of big problems faced by Indonesia on the transition to the strengthened democracy which is very complex. As for the main problem on this writing is: how do the political party evocate the conscience of public participation on the grassroots level causing shifts to voter's orientation?

This writing is trying to describe the phenomena of shifting behavior of voters on grassroots level, in Jombang district, especially prior to Presidential Election in 2009 and Regional Election (in East Java and Jombang) done at the same time on July 2008.

\section{Theoritical Framework}

In political science, the voter's behavior shifting phenomena could be included as a part of participatory studies. Public participation is the activity of citizens who act as an individual intending to influence government decision making process. Participation may take place as individual or collective, spontaneous or organized, legal or illegal, integrated or sporadic, amicably or by force (Budiardjo, 1976, 2009).

Based on that participation concept, we could make a simple logic. First, when the public participation is higher, it will make the governance better, the high and low of participation level is not only determined by the quantity of the voters but also more essentially is determined by the frequency, continuity and the consistency of the people involvement on the state matter. Participation can be differentiated between the autonomous participation which is participation that grow voluntary and without manipulation, and mobilized participation which is participation that grows involuntary, with manipulation and intimidation.

Second, in the context of local politics in the transitional democracy condition, the strengthening of public participation is urgent as a part of democratic political process. Public participation at the grassroots level legally and formally is not only needed to be a reference to create the balance relationship between political party functionaries and its constituents and supporters at the grassroots level.

Whereas the voters behavior relate with the participation of the grassroots is part of local politics phenomena. In the context of this writing, the understanding of public participation can be done by elaborating several approaches which offered by Diamond (2003) and Christensen (1995) as below.

First, is the elite approach (actor) which put forward commitment between elites through coordination mechanism based on constitution, political institution, and agreement pacts to establish the boundaries of state authority without regarding which political party is on power. Second, institutional approach, is the institutionalization of politics and enhancement of regime performance. The deepening makes the formal structure of democracy be more liberal, accountable, representative and accessible, this thing also makes possible for the creation of freedom and law compliance. Political institutionalization is an effort for strengthening the representative democracy structure and formal governance. Whereas the regime performance should be seen as an effort to result an output policy which positive enough to build political legitimation or to avoid the creation of resistance knots in the community. Third, is the political cultural approach, relate with perception, attitude, support, action and also beliefs about the importance of democratic legitimation. Democracy is believed as the most possible government to implement, this thing is not only manifested by voting, but also with political interest, information, knowledge, opinion formation and also organizational membership. Therefore, the basic political orientation of the participants will increase if the people self-confidence and competency for their political action can result a change. Fourth, is an approach which puts forward the civil society existence. Civil society is the social life sphere organized openly, voluntarily, and self-generating or at least the social life which is independent partially and autonomic from state but bound by legal set up or collective values. Civil society become important because it may foster democracy vitality through five ways which are helping the emergence of values and democratic skills, increasing accountability and people responsiveness towards interest and local matters, giving additional access for marginalized citizens, increasing the check and balances skill towards powers, and giving opportunity for political party and opposition factions to implement the influence to local level.

Whereas democratic process at the local setup, going naturally based on believed values and agreed by people collectively. The existence of representative assembly or the regional deliberation assembly is the tool which performs procedural democracy, this thing shows that there is a spirit for democracy which basically not only need representative assembly but also need reactualization of local wisdom because the entry of modern and universal values which shifting the local wisdom itself ${ }^{3}$.

Based on that theoretical framework above, this writing try to adopt theoretical approach which is relevant with

${ }^{3}$ Annual Report 2001-2002, Institute for Research and Empowerment, Yogyakarta, 2002, pp. 15-16, 18-21. 
the necessity, that is institutional approach as the main approach. The implementation of this approach is based on two reasons which is firstly, the general condition of political life in Indonesia and especially in the local context still exist on the transitional condition which tends to put forward development of formal political institution than the truly development of democracy which fully based on political elements (political party) and civil society as in modern democracy living.

Secondly, in the local political process, even though normatively and formally is important part, but functionally governance still has strong tendency to play its role on political life. Therefore, in understanding local politics, "state" should be placed proportionally as an actor who is actively running political machine at local level similarly with the role of political party, political elites and civil society (Evans et al., 1987). Thus, this approach is not closing the possibility to use the particular elements of elite, political cultural and civil society approaches.

\section{The Shifting Behavior of Voters: Jombang Case}

The shifting behavior at the grassroots level in Jombang district overlapped with the culture of local politics. However this still can be differentiated into two patterns: the general pattern and specific pattern. General pattern of public participation is the existence of process and procedure which applied generally and formed based on provisions which has been fixed by political institution and formal governance such as Acts, government regulation, regional regulation, governor regulation, and memorandum agreement between political institution, government institution and non-state social institution. This general pattern applied in urban community and also rural community. While the high and low and public participation frequency is really depended on the social, political and economic environment, effectiveness of political socialization, the growth and emergence of political consciousness.

Whereas the specific pattern of public participation is participation which emerged in the undercurrent community. Based on field observation that public participation in urban and rural area in Jombang district based on the socio-cultural condition, in santri community dichotomy was symbolized with green color and non-santri community or $a_{b a n g^{4}}$ was symbolized with red color. This differentiation showed the different political orientation which was followed by people, effectiveness of political socialization (such as things related with the election of public officer), growth and emergence of political elites consciousness (such as political elite who is fully or partly involved in political activity) and emergence of people political consciousness (such as people who is voluntarily or autonomously active in political activity on their capacity as individual or non-state social institution or non-governmental organization).

The general pattern above was static or artificially was not easy to shift if some regulations had been made by the people representative or regional political leaders was not changing. But specific pattern was vulnerable towards changes caused by issues rooted from the geographic-economics and socio-religious condition.

The geographic-economics sourced from two related things. The geographical condition related with space aspect describing differences or similarities between one region and another region, and also describing the physical facilities which sustained community mobility level, whereas the economic condition related with source or regional economic potential. These things became the basic of community participation characteristics. While the socio-religious related with community beliefs and values which shaped values and social norms in particular region. In other words, those two conditions had strong tendency for the voters shifting behavior.

Geographically Jombang district located in the middle of East Java province and the strategic crossing-gate area between Surabaya-Madiun and Malang-Babat (Lamongan district). On the east bordered with Mojokerto district, Kediri district and Malang district on the south, Nganjuk district on the west and Lamongan district on the north. Jombang district was not only located in the outskirts of growth area GERBANGKERTOSUSILA (Gresik, Bangkalan, Mojokerto, Surabaya, Sidoarjo and Lamongan), but also based on urban planning of the East Java province that Jombang had included GERBANGKERTOSUSILA Plus, besides of Pasuruan.

On the territorial concept made by the governance that Jombang district divided into three sub-areas. 1) The north zone, was a part of the Kendeng mountain which had physiologically flat and half part hilly area. Areas which had similar characteristics included Plandaan, Kabuh, Ploso, Kudu and Ngusikan sub-districts. 2) Middle zone, was the south side of Brantasriver where this areas were agricultural areas which could be cultivated with rice and crops. Areas which had similar characteristics included Bandar Kedungmulyo, Perak, Gudo, Diwek,

\footnotetext{
${ }^{4}$ Santri in Javanese society defined as Muslims who practicing their Islamic ritual in daily life, this community always symbolized in green color. Abangan defined as Muslims but lax of practicing Islamic ritual in their daily life, this community always symbolized in red color.
} 
Mojoagung, Sumobito, Jogoroto, Peterongan, Jombang, Megaluh, Tembelang and Kesamben sub-districts. 3) South zone, was the mountains areas which could be cultivated by plantations. Areas which had similar characteristics included Mojowarno, Ngoro, Bareng and Wonosalam sub-districts.

Besides those things, the economics in Jombang district mainly sustained with agricultural industry such as farm, plantation and forestry ${ }^{5}$. The farm industry covered areas of 48.320 hectares or $42.19 \%$ of Jombang areas, $82.07 \%$ of technical rice field, $10.36 \%$ of rainfedrice field, $3.44 \%$ of half technical rice field, $2.86 \%$ of simple rice field and 1.27\% (unknown), this main farm areas were Bareng and Sumobito sub-districts. Whereas main plantation industries were coffee, clove, cocoa, tobacco, and sugarcane. The coffee plantation covered 1182.55 hectares, clove areas of 2297.63 hectares and cocoa areas of 494 hectares which only existed in Wonosalam and Bareng regions, tobacco plantations of 2180.50 hectares with plantation location spread in Kudu, Ngusikan, Ploso, Kabuh and Plandaan and sugarcane plantations of 9871.67 hectares with location spread in some sub-districts. The forestry industry only covered 19651.66 hectares areas which consisted of production forest of 14868.10 hectares, conservation forests of 873.10 hectares, tebangpilih forests of 1045.70 hectares and national sanctuary/national park of 2.864 hectares.

Jombang district had two different sides. On one side was urban and rural area. Urban area was areas which had characteristics such as: the existence of transportation and communication facilities such as adequate road access, the existence of economic facilities such as market, bank and others, the existence of education facilities such as educational institutions at senior high school level and near with industrial area. These areas mostly located in the middle zone or along the roadside of the province which can be differentiated between the east and south area of the district capital such as Jombang, Mojoagung, Peterongan, Diwek and the west side area of Jombang city such as Perak and Bandar Kedungmulyo sub-districts.

Whereas rural area was areas with characteristics such as: the existence of transportation and communication facilities which were not adequate and isolated, there were no economic facilities such as markets, banks, and others, there were no education facilities, minimum at senior high school level, and far from the industrial location. Rural areas of Jombang district can be differentiated between the north Jombang and South Jombang. North Jombang was the farming areas which located along the Brantasriver which divided into two parts that were north side and west side, which mostly planted with oaks and located on a little barren calcareous area. These areas were Plandaan, Ploso, Kudu and Ngusikan sub-districts, while the south and east sides were fully fertile farming areas which included on it, Ploso and Kudu sub-districts. Whereas in the south Jombang was the farming areas which located in the foot of the mountain, included Ngoro, Bareng and Wonosalam sub-districts.

The socio-religious was the combination of two related things. Nominally the emergence of the total population and the emergence of the total of particular religious congregation could be indicated by the total worship places. According to the notes of Central Statistics Bureau of Jombang district that the population in this region increased on the average $5 \%$ every year.

The relation between the citizen and religion could be seen from the empirical indication that was the worship places showed that Muslims were totally the largest amount in quantity (with 1,188,361 people) both and urban and rural areas in total. Whereas the Protestant Christian and Rome Catholic Christian were respectively in the second and third rank with respectively 14,865 people and 3563 people. Individually (per sub-districts) the biggest Muslim population in urban area was the Jombangsub-district with 115,763 people and the smallest population was in Peterongan sub-district with 57,525 people, whereas the biggest Protestant Christian population in urban area was in Jombangsub-district with 3350 people and the smallest population was in Diweksub-district with 180 people. Moreover in rural area, the biggest Muslim population was in Sumobito sub-district with 93,632 people and the smallest population was in Ngusikan sub-district with 20,755 people. Whereas the biggest Protestant Chistian population in rural area was in Mojowarno sub-district with 4000 people and the smallest population was in Jogoroto (zero).

The total population and the religion worshippers in urban and also rural on this writing was important to explain the relationship between the socio-religious condition and the tendency of voters shifting behavior from collective-religious to individual-rational.

With urban-rural setting which fueled by geographic-economic and socio-religious condition, the voters shifting behavior at grassroots level could be determined by some factors. First, was the losing faith of the community towards the traditional elite Jombang which was known since long ago as the santri area, in this area culture became the adhesive factor of patronage relationship between kyai and santri, santri was no longer became

\footnotetext{
${ }^{5}$ See, Jombang Dalam Angka (Jombang Regency Annual Report), 2007.
} 
the reference to determine people political choice. One of the causes was the inconsistence political behavior of the kyai and Islamic political elites which easily moved from one party to another party, especially to those parties which not Islamic parties. In this case, voter's behavior was not determined by the traditional Islamic elites anymore but more on individually and rationally consideration.

Second, the weak government control over the people. Towards national and Presidential Elections 2009 and Regional Election 2008, the large political parties such as Golkar, PKB and PDI P were using the political rift which left by bureaucracy. This thing was as the logical consequences of the changing of bureaucrats and security roles in the region that were previously as the political constructor to be fully public servant.

That political rift existed at the village governance level where Village Deliberation Assembly (BPD) existed. This assembly was used by political party as the new political arena to build supporter basis at grassroots level, this thing happened especially towards the election of village chief officer which will had done at the same time in the mid of 2007. So the conflicts at the village scale arouse to fight for Village Deliberation Assembly (Badan Permusyawaratan Desa/BPD) membership.

Third, the money politics had more emerged. At this time, national election, regional election and even village election by people at the grassroots level considered as the moment to gain incomes (money or goods) from public officer candidates. Every candidates (or prospective candidates) must be had successful team which considered by people as team which spread money to the voters to influence the prospective voters vote with many kinds of donations. The consequence from these money politics was that every candidate should prepare big amounts of money to run in the election.

Therefore, in this case study, there is a strong tendency that voters behavior was not using or trapped on cultural dichotomy of ijo culture (santri) and abangan (abangan/priyayi) anymore but more on daily concrete issues consideration.

\section{Conclusion}

To conclude, there are two points. First, the voters shifting behavior was a common thing if that shifting came from the people itself. Here people needed political education which not only was for the interest of the political party in gaining powers but also should consider the voter's aspiration. Second, political party had responsibility to create public participation, if they only considered the individual and group's interest, the journey to build democratic political system would be more far away and the effort for reformation that had to be done would be such a waste.

\section{References}

Budiardjo, M. (1979, 2009). Dasar-Dasar Ilmu Politik. Jakarta.

Christensen, T. (1995). Local Politics: Governing at the Grassroots. Belmont, California: Wadsworth Publishing Company.

Diamond, L. (2003). Developing Democracy: Toward Consolidation. Yogyakarta: Institute for Research and Empowerment (IRE).

Evans, P. B. et al. (1987). Bringing the State Back in. Cambridge: Cambridge University Press.

Mochtar, H. (2008). Partisipasi Publik Dan Budaya Politik Pemilih: Studi Kasus Perilaku Pemilih “Grassroots” Kabupaten Jombang. National Seminar XXII of Indonesia Political Science Association, Banjarmasin.

Mochtar, H. (2012). Demokrasi Dan Politik Lokal Di Kota Santri (Democracy and Local Politics in Urban Muslim's). Malang: Brawijaya University Press.

Jombang Dalam Angka (Jombang Annual Report) (2007). BAPPEDA, Jombang. 
Scientific Research Publishing (SCIRP) is one of the largest Open Access journal publishers. It is currently publishing more than 200 open access, online, peer-reviewed journals covering a wide range of academic disciplines. SCIRP serves the worldwide academic communities and contributes to the progress and application of science with its publication.

Other selected journals from SCIRP are listed as below. Submit your manuscript to us via either submit@scirp.org or Online Submission Portal.
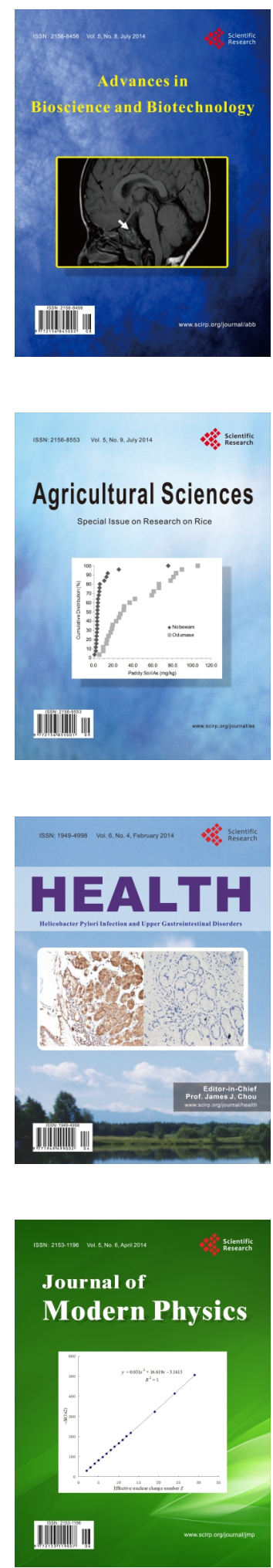
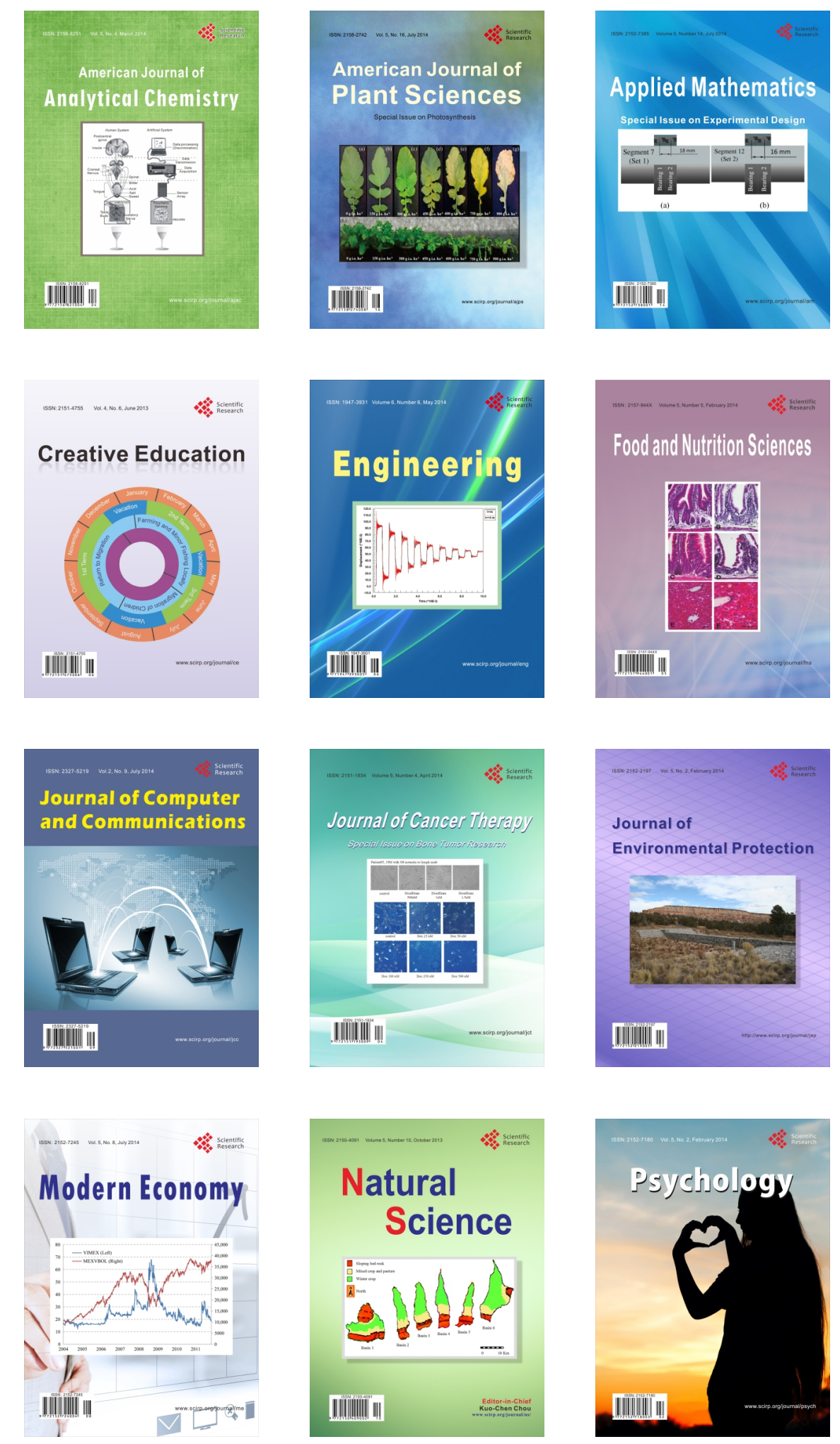